Review

\title{
Magnetically stabilized bed reactors
}

\author{
ZONG Baoning*, MENG Xiangkun, MU Xuhong, ZHANG Xiaoxin \\ State Key Laboratory of Catalytic Material and Reaction Engineering, Research Institute of Petroleum Processing, SINOPEC, Beijing 100083, China
}

\section{A R T I C L E I N F 0}

\section{Article history:}

Received 20 August 2012

Accepted 26 November 2012

Published 20 January 2013

\section{Keywords:}

Magnetically stabilized bed

Magnetic catalyst

Selective hydrogenation

Carbon monoxide methanation

Olefin oligomerization

Industrialization

\begin{abstract}
A B S T R A C T
The first commercial application of the magnetically stabilized bed (MSB) reactor is discussed. The MSB reactor uses a magnetic catalyst in a uniform magnetic field to combine the many advantages of the fixed bed, slurry bed, moving bed, and fluidized bed reactors. An industrial MSB reactor requires a large and uniform magnetic field, which was obtained by optimizing the coil installation spacing and inserting magnetic grids in the reactor. It was used for the intensification of the hydrogenation processes by operating in the chain mode. By utilizing the excellent hydrogenation activity and magnetism of an amorphous Ni catalyst, a MSB reactor was developed for the hydrorefining of caprolactam. Five industrial units of 200-400 kt/a production capacity have been built since 2003 . The use of the appropriate magnetic catalyst in the MSB reactor also enhanced activities in CO methanation, selective acetylene hydrogenation and olefin oligomerization. This technology gives new opportunities for process intensification.
\end{abstract}

(C) 2013, Dalian Institute of Chemical Physics, Chinese Academy of Sciences. Published by Elsevier B.V. All rights reserved.

\section{Introduction}

Reactor technology is important in all chemical transformations. In the 20th century, reaction engineering first played a pivotal role in the successful development of various reactor technologies in the petrochemical industry, which were then used in the manufacture of polymers, composites, and fibers. In the past thirty years, although petrochemical enterprises all over the world have invested heavily in developing reactor technology, the petroleum and chemical industries still mainly used the slurry bed, fixed bed, moving bed, and fluidized bed reactors. Upgrading of the petrochemical industry technology must rely on the integration and innovation of catalytic materials and reactor technology [1].

The magnetically stabilized bed (MSB) reactor consists of ferromagnetic particles subjected to a spatially uniform and time invariant magnetic field directed axially with a fluidizing flow. The features of the MSB reactor and four other reactors are briefly summarized in Table 1 . Similar to the slurry bed reactor, the MSB reactor can use fine particle catalysts. Similar to the fixed bed reactor, the catalyst can be kept in the MSB. Similar to the moving bed reactor and fluidized bed reactor, the catalyst can be replaced in the reaction process. In conclusion, the MSB reactor combines the advantages of existing reactors such as a low pressure drop and high mass/heat transfer efficiency, and even more important, the MSB reactor has no special requirements for catalyst strength, size, shape, and activity stability.

Since the pioneering reports of Filippov [2] in the early 1960 s, there have been a large number of publications on the MSB reactor, and it was the subject of an important pioneering research development program in Exxon Corporation [3]. Early interest in the MSB reactor was mainly centered on gas-solid reactors [4-9]. Up to now, the performance of liquid-solid and gas-liquid-solid MSB reactors have not been well characterized $[10,11]$. Hu et al. [12] examined liquid-solid and gas-liquid-solid MSBs containing magnetic particles and determined the effect of the magnetic field intensity on the overall and radial gas

\footnotetext{
* Corresponding author. Tel/Fax: +86-10-82368011; E-mail: zongbn.ripp@sinopec.com 
Table 1

Features of some reactors.

\begin{tabular}{|c|c|c|c|c|c|c|c|c|}
\hline \multirow{2}{*}{ Reactor } & \multirow{2}{*}{ Investment } & \multirow{2}{*}{$\begin{array}{l}\text { Operation } \\
\text { cost }\end{array}$} & \multirow{2}{*}{$\begin{array}{l}\text { Operation } \\
\text { flexibility }\end{array}$} & \multirow{2}{*}{$\begin{array}{c}\text { Mass/heat } \\
\text { transfer }\end{array}$} & \multicolumn{4}{|c|}{ Catalyst requirements } \\
\hline & & & & & Stability & Strength & Size & Shape \\
\hline Slurry bed & $\mathrm{L}$ & $\mathrm{L}$ & $\mathrm{M}$ & $\mathrm{L}$ & $\mathrm{L}$ & $\mathrm{L}$ & $\mathrm{L}$ & $\mathrm{L}$ \\
\hline Fixed bed & M & $\mathrm{L}$ & $\mathrm{L}$ & $\mathrm{L}$ & $\mathrm{H}$ & $\mathrm{H}$ & $\mathrm{H}$ & $\mathrm{H}$ \\
\hline Moving bed & $\mathrm{H}$ & $\mathrm{H}$ & M & M & M & $\mathrm{H}$ & $\mathrm{H}$ & $\mathrm{H}$ \\
\hline Fluidized bed & $\mathrm{H}$ & $\mathrm{H}$ & M & $\mathrm{H}$ & $\mathrm{L}$ & $\mathrm{H}$ & $\mathrm{H}$ & $\mathrm{H}$ \\
\hline MSB & M & M & $\mathrm{H}$ & $\mathrm{H}$ & $\mathrm{L}$ & $\mathrm{L}$ & $\mathrm{L}$ & $\mathrm{L}$ \\
\hline
\end{tabular}

H-highly difficult; M-medium; L-low or easy.

holdup. They found that the overall gas holdup increased with increasing magnetic field intensity. The radial profiles of both gas and solid holdups could be expressed by a parabolic equation under zero or weak magnetic fields. When the fields are strong, the phase holdup distributions become more uniform, and the solid holdup is similar to that of a fixed bed reactor. Kwauk et al. [13] examined bubble properties in a three phase MSB reactor with different liquid velocity, gas velocity, particle size, and surface tension. They found that both the bubble size and bubble rise velocity decreased with increasing magnetic field intensity. Thompson and Worden [14] presented experimental measurements of gas holdup and liquid axial dispersion in three phase MSB reactors. They found that the average gas holdup was decreased by as much as $20 \%$ with increasing magnetic field intensity.

However, the MSB reactor has not been used on the commercial scale because it needs a spatially uniform magnetic field with fluidized magnetic particles at a relatively low temperature, which require catalytic materials with magnetism and low temperature catalytic activity. Recently, a novel amorphous Ni alloy catalyst for hydrogenation was developed at Research Institute of Petroleum Processing, SINOPEC [15,16]. This catalyst is ferromagnetic, and it has high hydrogenation activity at low temperatures. By taking advantage of the ferromagnetic property of the amorphous $\mathrm{Ni}$ alloy catalyst and the high mass transfer efficiency of the MSB reactor, systematic work on the application of liquid-solid and gas-liquid-solid MSB reactors in the field of petrochemical processing was carried out [17-21]. In this paper, the research and applications of the MSB reactor in the petrochemical industry are presented. Some of the scientific challenges and opportunities in this field are discussed.

\section{Hydrodynamic characteristics of the MSB reactor}

To better understand the mechanism of fluidization in the MSB reactor, a cold model experimental apparatus with a diameter of $140 \mathrm{~mm}$ was set up (Fig. 1). The hydrodynamic characteristics of the liquid-fluidized MSB reactor with the amorphous Ni alloy catalyst as the solid phase and water as the liquid phase were investigated. The operating phase diagrams of the liquid-fluidized MSB reactor with the amorphous Ni alloy catalyst of four different sizes were obtained. Mathematical models of minimum fluidization velocity, transition velocity, and bed voidage were established [22].

Visual observations showed that three operating regimes

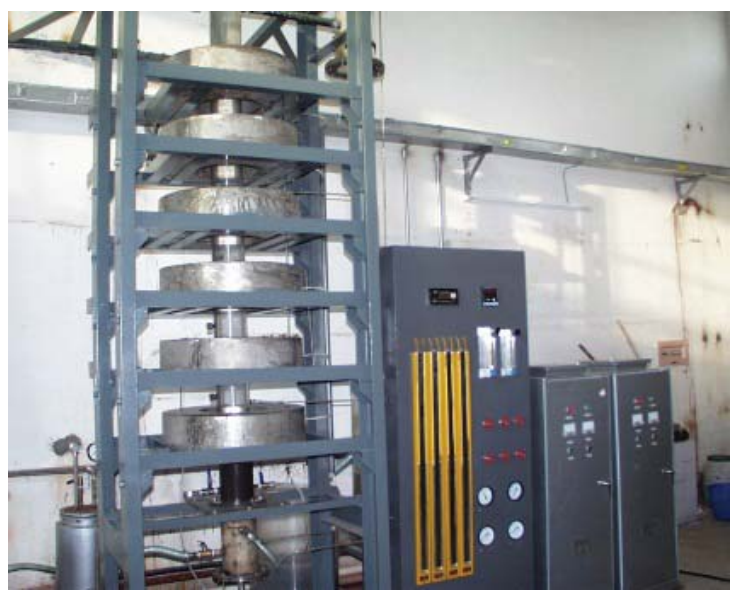

Fig. 1. Experimental apparatus of the MSB reactor.

existed according to the magnetic field intensity when the system was run at different fluid velocities. These are the particulate regime, chain regime, and magnetic condensation regime (Fig. 2). In a weak magnetic fie ld, the bed is operated in the particulate regime. In this regime, the catalyst particles move freely. On increasing the magnetic field intensity, the particles coalesce and formed chains along the direction of the field, and the bed is operated in the chain regime. When the magnetic field becomes too strong, the whole bed gets aggregated and the bed can no longer be fluidized. In the particulate regime and chain regime, the bed heights decrease with increasing magnetic field intensity, but in the magnetically condensed regime, the bed height is constant. When the bed is operated in the particulate regime, backmixing, and particle entrainment occurs. In the magnetic condensation bed, bypassing occurs and the catalyst surface is not fully available. In the chain regime, the bed voidage is uniform and the bed is operated in a stably state. The chain regime is the optimum state for the reaction process.

The pressure drop measured across the bed as the liquid velocity was increased in a magnetized bed was found to be

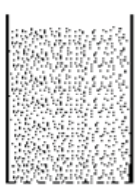

Particulate

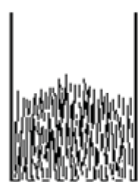

Chain

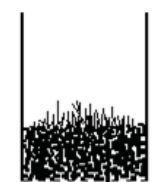

Magnetic condensation
Fig. 2. Bed structure of the MSB. 


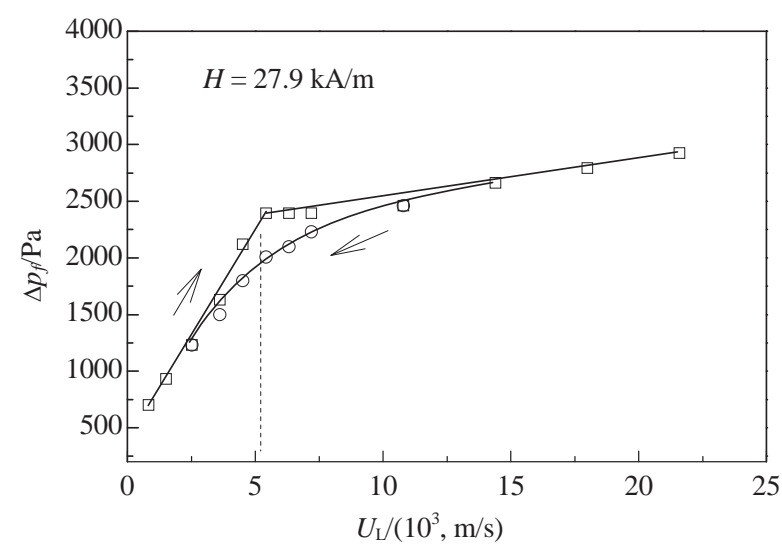

Fig. 3. Pressure drop profile for the L-S MSB reactor.

similar to that for a non-magnetized bed. The pressure initially increased until the minimum fluidization velocity was reached, and then remained constant at the bed weight support value as the liquid velocity was further increased. When the liquid velocity was decreased, the pressure drop was found to immediately fall below the bed support value, and it continued to decrease as the liquid velocity was decreased. Figure 3 shows this pressure drop profile for the liquid-solid MSB reactor.

Figure 4 shows the phase diagram of the liquid-solid MSB reactor with water and the amorphous Ni alloy catalyst. With increasing liquid velocity, several regimes existed for the MSB. These include the packed regime where the liquid velocity was lower than the minimum fluidization velocity, the stable regime where the liquid velocity was between the minimum fluidization velocity and the transition velocity, and the random motion regime where the liquid velocity was higher than the transition velocity. The liquid velocity and magnetic field intensity must be carefully controlled to keep MSB reactor operating within the chain regime.

\section{Local heat and mass transfer properties in the MSB reactor}

Heat transfer coefficients were measured by horizontal cylindrical probes immersed in co- and counter-current G-L-S MSB reactors using air, water, and amorphous Ni alloy catalyst

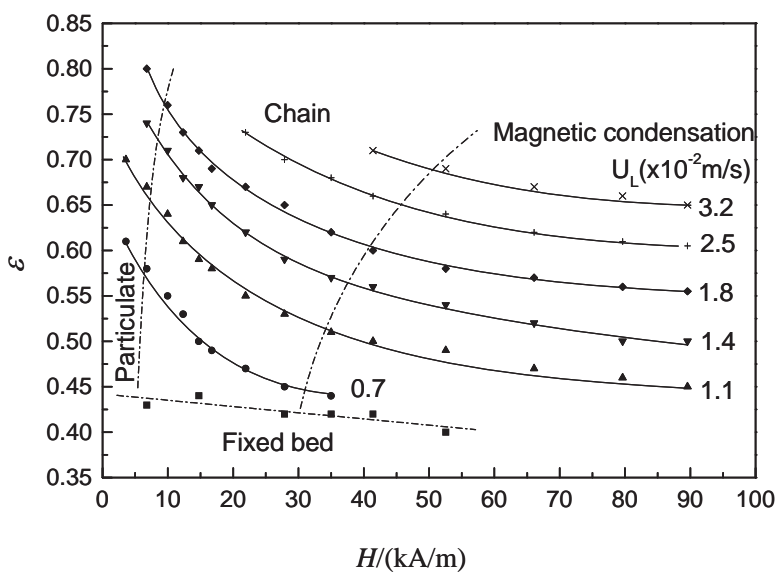

Fig. 4. Phase diagram of the L-S MSB reactor. particles as the gas, liquid, and solid phases, respectively. The influences of the major factors including magnetic field intensity, superficial gas and liquid velocities, liquid viscosity and surface tension on the heat transfer behavior of the G-L-S MSB reactor were studied [23]. For the cocurrent G-L-S MSB reactor, the heat transfer coefficient decreased with increasing magnetic field intensity. While operating at constant magnetic field intensity, the heat transfer coefficient in the G-L-S MSB reactor was enhanced by increasing the superficial gas or liquid velocity, or by reducing the liquid viscosity or surface tension. For the countercurrent G-L-S MSB reactor, the heat transfer coefficient also decreased with magnetic field intensity and it can be changed by other operation parameters. The heat transfer coefficients for the G-L-S countercurrent MSB reactor were approximately twice those for the cocurrent MSB reactor, although the superficial gas velocities for the countercurrent MSB reactor were almost ten times those of the cocurrent MSB reactor. Two correlation equations were proposed for estimating the heat transfer coefficients for the co- and countercurrent G-L-S MSB reactors. The experimental results indicated that both the co- and countercurrent G-L-S MSB reactors can provide relatively uniform radial profiles of the heat transfer coefficient under appropriate operation conditions. Due to its giving of the advantage of robust temperature control without runaway conditions, the uniform heat transfer property is promising for the application of the G-L-S MSB reactor for highly exothermic heterogeneous reactions.

Combining the experimental results with the parameters of magnetic field intensity, superficial velocities of gas and liquid, liquid viscosity, and surface tension gave the following correlations for estimating the heat transfer properties for the co- and countercurrent G-L-S MSB reactors with an average error of less than $10 \%$.

Cocurrent:

$$
\mathrm{Nu}=41.42\left(\operatorname{Re}_{\mathrm{L}}+\mathrm{Re}_{\mathrm{G}}\right)^{0.34} \operatorname{Pr}^{0.2} \mathrm{Bo}^{0.67}(1-\mathrm{H} / \mathrm{Ms})^{0.6}
$$

Countercurrent:

$$
\mathrm{Nu}=3.43\left(\operatorname{Re}_{\mathrm{L}}+\mathrm{Re}_{G}\right)^{0.128} \mathrm{Pr}^{-0.002} \mathrm{Bo}^{0.087}(1-\mathrm{H} / \mathrm{Ms})^{0.06}
$$

$\mathrm{Re}_{\mathrm{L}}$ and $\mathrm{Re}_{\mathrm{G}}$ represent the Reynolds number of the liquid and the gas phase, respectively. Pr is the Prandtl number, Bo is the bond number, $\mathrm{H}$ is the magnetic field intensity, and Ms is the saturated magnetization of the solid magnetic particles. These equations are applicable to the G-L-S MSB reactor operating in the range of $0.03<\operatorname{Re}_{L}<1.2,0<\operatorname{Re}_{G}<0.8$. From the exponential indices of the terms on the right hand sides of the above equations, it is worth noting that the external magnetic field plays a more significant role in the cocurrent MSB reactor than in the countercurrent MSB, which is consistent with our experimental results.

An electrochemical technique was used for the measurement of the local mass transfer coefficient in the liquid-solid MSB reactor with the amorphous Ni alloy catalyst particles [24]. The experimental results showed that the liquid-solid MSB reactor exhibited a slight decrease in mass transfer rates as compared with conventional fluidized beds operated under the same conditions. The liquid superficial velocity had almost no effect on the mass transfer coefficient in the operating condition of the magnetically stabilized regime. The liquid solid 
mass transfer coefficient decreased with increasing liquid viscosity. The results also showed that particles with bigger diameters had higher mass transfer rates. The mass transfer rates were constant at all radial positions except near the wall.

Mass transfer in the liquid-solid MSB reactor with the amorphous Ni alloy particle catalyst was studied under various conditions. The mass transfer coefficient decreased with the increase of magnetic field strength and liquid viscosity. An almost constant mass transfer coefficient was observed at a high flow velocity. Particles with bigger diameters had higher mass transfer rates. The mass transfer coefficient was the same at all radial positions except near the wall. The correlation for liquid-solid mass transfer was

$$
S h=1.49 \varepsilon^{-1.7092} \operatorname{Re}^{0.96} \mathrm{Sc}^{1 / 3}
$$

An uncritical use of conventional fluidized bed relationships for mass transfer in the liquid solid MSB reactor can cause significant overestimates of bed performance, especially at high flow rates.

\section{Case Studies of the MSB reactor}

\subsection{Hydrorefining of caprolactam in MSB reactor}

The hydrorefining of caprolactam solution is a key process for caprolactam production. In the conventional process, the hydrogenation of caprolactam solution is carried out in a slurry bed reactor with a Raney Ni catalyst. This process has the disadvantages of low hydrogenation efficiency, high catalyst consumption, and a limited ability to remove all detrimental impurities. We have combined the advantages of the MSB reactor and the amorphous Ni alloy catalyst, and developed a MSB reactor process for the purification of caprolactam.

The gas-liquid-solid MSB reactor was used in the laboratory scale hydrogenation of $30 \mathrm{wt} \%$ caprolactam solution. The 30 $w \mathrm{t} \%$ caprolactam solution and hydrogen were introduced into the MSB reactor from the bottom. Unsaturated impurities were converted into saturated molecules by hydrogenation in the MSB reactor. The purity of the caprolactam solution was expressed by the PM number (permanganate number). A higher PM number means a lower impurity content and a higher hydrogenation efficiency.

After the investigation of the effects of various operating conditions on the hydrogenation, the optimized reaction conditions were: temperature $60-90^{\circ} \mathrm{C}$, pressure $0.4-0.8 \mathrm{MPa}$, liquid hourly space velocity $30-50 \mathrm{~h}^{-1}$, hydrogen/liquid ratio $1.5-3.0$ $v / v$, and magnetic field intensity $15-25 \mathrm{kA} / \mathrm{m}$. Under these conditions, the PM number of the caprolactam solution can be increased from $100 \mathrm{~s}$ to $>3500 \mathrm{~s}$ [25]. Table 2 shows the comparison between hydrogenation in the MSB reactor and in a slurry bed reactor. The results showed that the hydrogenation efficiency in the MSB reactor was increased by 15 times and the catalyst consumption was decreased by $50 \%$ as compared with the slurry bed reactor and the Raney Ni catalyst.

Based on the laboratory scale study for the hydrogenation of caprolactam solution in the MSB reactor and the hydrodynamic characteristics of the MSB, a demonstration unit with the capacity of $6 \mathrm{kt} / \mathrm{a}$ pure caprolactam (equal to $20 \mathrm{kt} / \mathrm{a}$ production capacity of $30 \%$ caprolactam solution) was built for the engineering scale-up of the MSB reactor hydrogenation process [26]. The demonstration MSB reactor was $300 \mathrm{~mm}$ in diameter and $3 \mathrm{~m}$ in height. The feed was 30\% caprolactam solution.

Three different processes were tested to evaluate the effect of the various operating conditions on the hydrogenation of caprolactam solution and the stability of the catalyst: (1) the liquid-solid MSB reactor with dissolved hydrogen process in which the feed caprolactam solution was contacted with hydrogen in a mixer where hydrogen was dissolved in the caprolactam solution, followed by the separation of excess gaseous hydrogen from the caprolactam solution, which was then introduced into the MSB, (2) the gas-liquid-solid three phase MSB reactor process, and (3) a slurry bed reactor in combination with the liquid-solid MSB reactor process. The results of the demonstration unit showed that the PM number of $30 \%$ caprolactam solution can be increased from 40-60 s to 2000-4000 s by MSB reactor hydrogenation with any one of the three different processes. The efficiency was obviously higher than that of the slurry bed reactor, which could only give a PM number of 200-400 s. Among the three hydrogenation processes, the liquid-solid MSB reactor with dissolved hydrogen process gave the best result because this process has many obvious advantages, such as high hydrogenation efficiency, flexible operation, less catalyst carryover byproduct, and low labor needs. In the demonstration unit experiment, the lifetime of the amorphous Ni catalyst reached $3500 \mathrm{~h}$, the hydrogenation efficiency in the MSB reactor was increased by 20 times and the amorphous Ni catalyst consumption was decreased by $60 \%$ as compared with the slurry bed reactor and Raney $\mathrm{Ni}$ catalyst. The demonstration unit gave better results than the laboratory scale experiment.

\subsection{Combination of the MSB reactor and amorphous Ni alloy catalyst for $\mathrm{CO}$ methanation in hydrogen purification}

Most of the hydrogen produced today is by the steam reforming of hydrocarbon. In this process, a small quantity of $\mathrm{CO}$ inevitably remains in the hydrogen. The CO content must be reduced to $5-10 \mu \mathrm{g} / \mathrm{g}$ in order to avoid the poisoning of the catalysts in downstream processes. The current technology for

Table 2

Comparison of the MSB reactor and slurry bed reactor hydrogenation performance*.

\begin{tabular}{|c|c|c|c|c|c|c|c|c|}
\hline \multirow[b]{2}{*}{ Reactor } & \multirow{2}{*}{$\begin{array}{c}\text { Temperature } \\
\left({ }^{\circ} \mathrm{C}\right)\end{array}$} & \multirow{2}{*}{$\begin{array}{l}\text { Pressure } \\
(\mathrm{MPa})\end{array}$} & \multirow{2}{*}{$\begin{array}{c}\text { Liquid hourly } \\
\text { space velocity }\left(\mathrm{h}^{-1}\right)\end{array}$} & \multirow{2}{*}{$\begin{array}{c}\text { Hydrogen/liquid } \\
\text { rate }(v / v)\end{array}$} & \multirow{2}{*}{$\begin{array}{c}\text { Magnetic } \\
\text { field intensity } \\
(\mathrm{kA} / \mathrm{m}) \\
\end{array}$} & \multicolumn{2}{|c|}{ PM number $(\mathrm{s})$} & \multirow{2}{*}{$\begin{array}{l}\text { Catalyst consumption } \\
\text { (kg/ton caprolactam) }\end{array}$} \\
\hline & & & & & & $\begin{array}{c}\text { Feed caprolac- } \\
\text { tam solution }\end{array}$ & $\begin{array}{c}\text { Hydrotreated ca- } \\
\text { prolactam solution }\end{array}$ & \\
\hline MSB & 80 & 0.7 & 30 & 2.0 & 20 & 100 & 4000 & 0.1 \\
\hline Slurry bed & 90 & 0.7 & 2 & 2.0 & - & 100 & 800 & 0.2 \\
\hline
\end{tabular}

*Hydrorefining of caprolactam solution. 
Table 3

Comparison between the new process and commercial processes*.

\begin{tabular}{|c|c|c|c|c|c|c|c|c|}
\hline \multirow{2}{*}{ Process } & \multirow{2}{*}{$\begin{array}{c}\text { Catalyst } \\
\text { composition }\end{array}$} & \multirow{2}{*}{ Catalyst size } & \multirow{2}{*}{ Reactor } & \multirow{2}{*}{$T /{ }^{\circ} \mathrm{C}$} & \multirow{2}{*}{$P / \mathrm{MPa}$} & \multirow{2}{*}{$\begin{array}{c}\text { GHSV/ } \\
\mathrm{h}^{-1}\end{array}$} & \multicolumn{2}{|c|}{ CO concentration $(\mu \mathrm{g} / \mathrm{g})$} \\
\hline & & & & & & & in feed gas & in exit gas \\
\hline Petrochemical company ' $\mathrm{X}$ ' & $\mathrm{Ni} / \mathrm{Al}_{2} \mathrm{O}_{3}$ & $\Phi 6.5 \mathrm{~mm}$ & fixed bed & 280 & 3.1 & 6500 & 4700 & $<3$ \\
\hline Petrochemical company ' $\mathrm{Y}$ ' & $\mathrm{Ni}-\mathrm{Co} / \mathrm{Al}_{2} \mathrm{O}_{3}$ & $\Phi 2.5 \mathrm{~mm}$ & fixed bed & $260-285$ & 2.9 & 6500 & 2600 & $<10$ \\
\hline SRNA/MSB process & Amorphous Ni & $125-180 \mu \mathrm{m}$ & MSB & 160 & 3.0 & 50000 & $2000-2500$ & $<1$ \\
\hline
\end{tabular}

*CO methanation in hydrogen purification.

this is based on CO methanation with a supported Ni-based catalyst in a fixed bed reactor. In order to decrease the concentration of CO from $0.2 \%-0.4 \%$ to $5-10 \mu \mathrm{g} / \mathrm{g}$, the reaction must be operated at high temperature $\left(280-300{ }^{\circ} \mathrm{C}\right)$ and low gas velocity (3000-9000 $\mathrm{h}^{-1}$ ). In addition, because of the inherent disadvantages of the fixed bed reactor, it is difficult to achieve the long operational periods required in the petrochemical industry.

Table 3 shows a comparison of the overall CO methanation performance of the MSB reactor with those of two current commercial processes using fixed bed reactors [27]. Compared with the conventional processes, the operating temperature required for the MSB reactor process is about $100{ }^{\circ} \mathrm{C}$ lower while the gas hourly space velocity was increased by 8 times. These preliminary test results demonstrated that the new process has good prospects for application in the hydrogen purification process.

\subsection{Magnetic catalyst}

Other than the amorphous $\mathrm{Ni}$ catalyst, most commercial catalysts are non-magnetic. To meet the requirements of the MSB reactor or a magnetic separator, magnetic catalysts would have to be developed. To do this, the use of magnetic nanoparticles has emerged as a viable solution. A one-pot hydrothermal cohydrolysis-carbonization process was designed that used glucose and iron nitrate as starting materials, which succeeded in the fabrication of carbonaceous spheres embedded with highly dispersed iron oxide nanoparticles [28].

The magnetic nanoparticle was used as the magnetic core to prepare a magnetic $\mathrm{Al}_{2} \mathrm{O}_{3}$ support. A magnetic $\mathrm{NiSO}_{4} / \mathrm{Al}_{2} \mathrm{O}_{3}$ catalyst was prepared by the incipient wetness method, and it was evaluated as the olefin oligomerization catalyst using a light FCC gasoline feedstock in the MSB reactor [29]. A magnetic $\mathrm{Pd} / \mathrm{Al}_{2} \mathrm{O}_{3}$ catalyst was prepared by a similar method, and it was evaluated as the selective acetylene hydrogenation catalyst in the MSB reactor [30]. The integration of the state-of-the-art magnetic catalyst with the MSB reactor or magnetic separator will intensify the catalytic process to give new generation technologies.

\subsection{Light FCC gasoline olefin oligomerization with a magnetic $\mathrm{NiSO}_{4} / \mathrm{Al}_{2} \mathrm{O}_{3}$ catalyst in $\mathrm{MSB}$ reactor}

Olefin oligomerization is a promising approach for the production of clean diesel fuels free of sulfur and aromatics. Ni$\mathrm{SO}_{4} / \mathrm{Al}_{2} \mathrm{O}_{3}$ exhibits excellent catalytic performance in olefin oligomerization. On the other hand, olefin oligomerization is an exothermic reaction, which can lead to hot spots that adversely affect the operation of the catalyst due to the poor heat and mass transfer characteristics of the fixed bed reactor. The shortcoming of the fixed bed reactor has limited olefin oligomerization on a large commercial scale.

The magnetic $\mathrm{NiSO}_{4} / \mathrm{Al}_{2} \mathrm{O}_{3}$ catalyst was evaluated as an olefin oligomerization catalyst using a light FCC gasoline feedstock in both a fixed bed reactor and a MSB reactor (shown in Table 4). Although the average diesel yield in the MSB reactor was only slightly higher than that in the fixed bed reactor, the broad space velocity range possible in the MSB reactor indicated its excellent operational flexibility. It can be concluded that the integration of the magnetic $\mathrm{NiSO}_{4} / \mathrm{Al}_{2} \mathrm{O}_{3}$ catalyst with the MSB reactor has considerable potential for applications in olefin oligomerization [29].

\subsection{Selective acetylene hydrogenation with a magnetic $\mathrm{Pd} / \mathrm{Al}_{2} \mathrm{O}_{3}$ catalyst in $\mathrm{MSB}$ reactor}

A small quantity of acetylene impurity (about $0.3 \%-3.0 \%$ ) in the ethylene-rich fraction from the cracking of a hydrocarbon feedstock will poison an ethylene polymerization catalyst because acetylene can easily be converted into $\mathrm{C}_{6}-\mathrm{C}_{24}$ unsaturated hydrocarbons that adsorb on the catalyst surface. Selective catalytic hydrogenation is generally used to remove acetylene from the gas mixture.

The selectivity for acetylene hydrogenation is affected by heat and mass transfer to a significant extent. Because the reaction order of acetylene hydrogenation is higher than that of ethylene hydrogenation, slow mass transfer adversely affects the selectivity of the reaction. In order to increase the mass transfer coefficient, different catalyst support with novel shapes, such as the trifoliate or gear, have been employed, but such changes have been found to give minimal improvements due to the inherent disadvantages of the fixed bed reactor.

The acetylene hydrogenation performance of the magnetic $\mathrm{Pd} / \mathrm{Al}_{2} \mathrm{O}_{3}$ catalyst was compared with that of the commercial catalyst during their operation in the MSB reactor with and

Table 4

Comparison between the MSB reactor and the fixed bed reactor with the magnetic $\mathrm{NiSO}_{4} / \mathrm{Al}_{2} \mathrm{O}_{3}$ catalyst*.

\begin{tabular}{lccccc}
\hline Reactor & $\begin{array}{c}\text { Reaction } \\
\text { temperature } \\
\left({ }^{\circ} \mathrm{C}\right)\end{array}$ & $\begin{array}{c}\text { System } \\
\text { pressure } \\
(\mathrm{MPa})\end{array}$ & $\begin{array}{c}\text { LHSV } \\
\left(\mathrm{h}^{-1}\right)\end{array}$ & $\begin{array}{c}\text { Magnetic } \\
\text { field } \\
\text { intensity } \\
(\mathrm{kA} / \mathrm{m})\end{array}$ & $\begin{array}{c}\text { Diesel } \\
\text { yield (\%) }\end{array}$ \\
\hline MSB & $170-190$ & 3.0 & $2.0-6.0$ & 30.0 & $39.7-45.6$ \\
Fixed-bed & 190 & 3.0 & $1.0-2.0$ & - & $37.9-41.6$ \\
\hline
\end{tabular}

*Light FCC gasoline olefin oligomerization. 
Table 5

Comparison between the magnetic $\mathrm{Pd} / \mathrm{Al}_{2} \mathrm{O}_{3}$ catalyst and the commercial catalyst*

\begin{tabular}{|c|c|c|c|c|}
\hline \multirow[b]{2}{*}{$\begin{array}{l}\text { Space velocity } \\
\left(\mathrm{h}^{-1}\right)\end{array}$} & \multicolumn{2}{|c|}{$\mathrm{X}\left(\mathrm{C}_{2} \mathrm{H}_{2}\right) / \%$} & \multicolumn{2}{|c|}{$\mathrm{S}\left(\mathrm{C}_{2} \mathrm{H}_{4}\right) / \%$} \\
\hline & $\begin{array}{l}\text { Magnetic } \\
\mathrm{Pd} / \mathrm{Al}_{2} \mathrm{O}_{3} \\
\end{array}$ & $\begin{array}{c}\text { Commercial } \\
\text { catalyst }\end{array}$ & $\begin{array}{l}\text { Magnetic } \\
\mathrm{Pd} / \mathrm{Al}_{2} \mathrm{O}_{3}\end{array}$ & $\begin{array}{c}\text { Commercial } \\
\text { catalyst }\end{array}$ \\
\hline 3000 & 100 & 100 & -11.2 & -65.8 \\
\hline 6000 & 100 & 92.7 & 68.0 & 23.5 \\
\hline 9000 & 100 & 78.1 & 80.6 & 46.9 \\
\hline 12000 & 100 & 36.6 & 83.7 & 63.8 \\
\hline 18000 & 98.6 & 13.8 & 84.2 & 65.5 \\
\hline 24000 & 95.1 & 2.7 & 82.6 & 70.1 \\
\hline
\end{tabular}

*Selective acetylene hydrogenation.

without a magnetic field, with all the other reaction conditions remaining unchanged. Compared with the commercial catalyst, the magnetic $\mathrm{Pd} / \mathrm{Al}_{2} \mathrm{O}_{3}$ catalyst gave a markedly superior performance in the selective hydrogenation of acetylene at high space velocities. When the space velocity was in the range $6000-18000 \mathrm{~h}^{-1}$, the selectivity to ethylene reached $68 \%-84 \%$ and the conversion of acetylene could be maintained at more than $98 \%$ (Table 5). It can be expected that the integration of the magnetic $\mathrm{Pd} / \mathrm{Al}_{2} \mathrm{O}_{3}$ catalyst with the MSB reactor will have considerable potential for applications in selective acetylene hydrogenation [30].

\section{Industrial application of MSB reactor}

In 2003, a $60 \mathrm{kt} / \mathrm{a}$ caprolactam hydrofining unit MSB reactor (equal to $200 \mathrm{kt} / \mathrm{a}$ production capacity of $30 \%$ caprolactam solution) was built by Shijiazhuang Chemical Fiber Company (Fig. 5). The MSB reactor was $900 \mathrm{~mm}$ in diameter and $5 \mathrm{~m}$ in height, and had six electromagnetic coils with an inner diameter of $1.1 \mathrm{~m}$ and a height of $680 \mathrm{~mm}$ for each coil. Checkup and testing of the electromagnetic coils showed that the radial variation of the magnetic field strength was less than $15 \%$, and the axial variation of the magnetic field strength was less than $5.7 \%$, while a long cycle lifetime and safe operation of the electromagnetic coils could be achieved by using water cooling. The

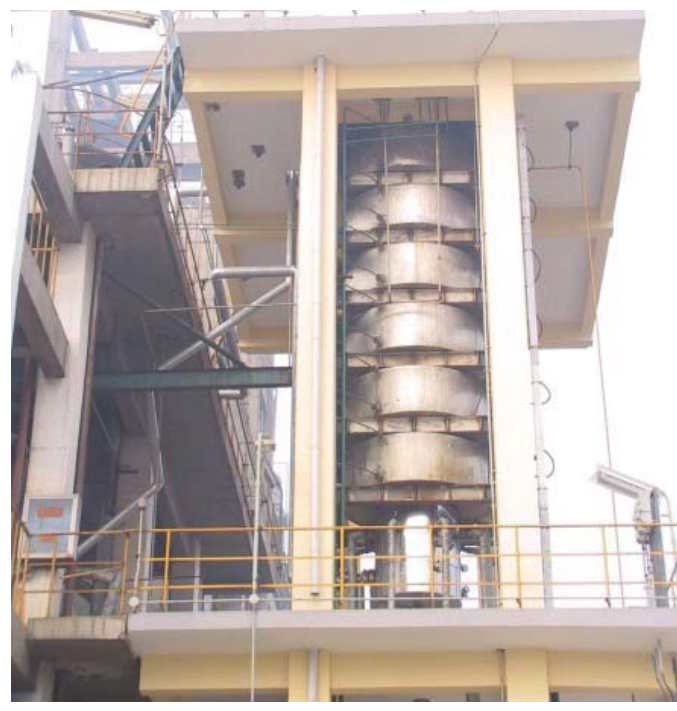

Fig. 5. A $200 \mathrm{kt} / \mathrm{a}$ industrial MSB reactor unit.

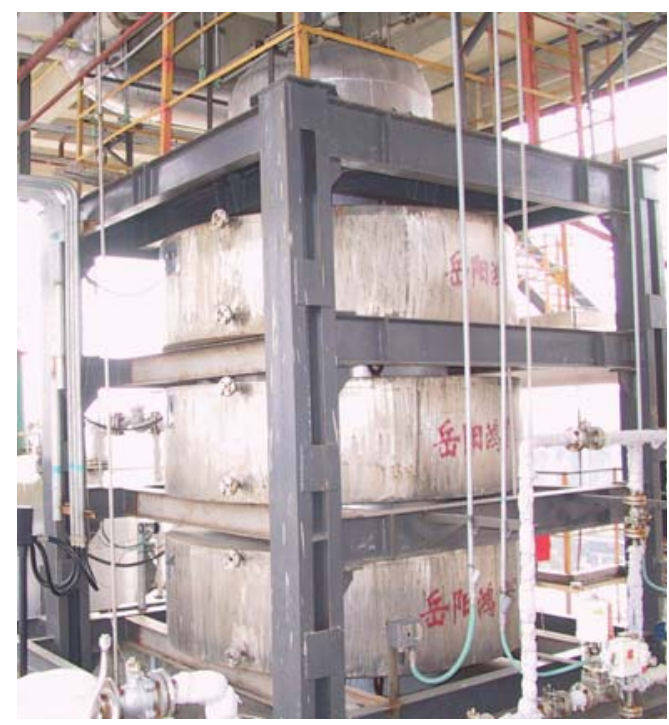

Fig. 6. A $300 \mathrm{kt} / \mathrm{a}$ industrial MSB reactor unit.

total power of the six coils was $7.2 \mathrm{~kW}$ which gave a magnetic field with a magnetic field strength of $27.1 \mathrm{kA} / \mathrm{m}$. The flow diagram of this commercial unit was as follows: preheated $30 \%$ caprolactam solution and hydrogen were mixed in a stirring tank in which hydrogen was dissolved in the caprolactam solution with simultaneous gas/liquid separation, and then the $30 \%$ caprolactam solution containing dissolved hydrogen was sent into the MSB reactor for the hydrorefining reaction by the amorphous $\mathrm{Ni}$ alloy catalyst. The commercial test results showed that this unit operated reliably and had the advantages of easy start-up and shut-down of the process unit and high hydrorefining efficiency. The reaction temperature was lowered by $10^{\circ} \mathrm{C}$, and the MSB reactor volume was $1 / 8$ of the slurry bed reactor while giving remarkable improvements in product quality. In 2004, a $100 \mathrm{kt} / \mathrm{a}$ caprolactam hydrorefining unit (equal to $300 \mathrm{kt} / \mathrm{a}$ production capacity for $30 \%$ caprolactam solution) was built at the SINOPEC Baling Petrochemical Branch Company [31,32]. There are now five industrial MSB reactor units in operation with $2 \mathrm{Mt} / \mathrm{y}$ total production capacity, and six industrial MSB reactor units are under construction.

\section{Conclusions}

The hydrodynamic characteristics of the liquid-fluidized MSB reactor with an amorphous Ni alloy catalyst as the solid phase showed three operating regimes versus the intensity of the magnetic field when the system was run at different fluid velocities. In the chain regime, the bed can be operated stably in a wide range of conditions with uniform voidage. The chain regime is the optimum state for performing reactions. Based on the laboratory scale study of the hydrogenation of caprolactam solution in the MSB reactor, the hydrodynamic characteristics of the MSB reactor, engineering scale-up work in a demonstration plant and other basic scientific research results, five industrial MSB reactor units with a total capacity of $2 \mathrm{Mt} / \mathrm{y}$ caprolactam solution have been commissioned. The commercial results showed that the hydrogenation efficiency in the MSB reactor 
was increased by 10 times and the catalyst consumption was reduced by $60 \%$ as compared with the slurry bed reactor.

In recent years, the rapid development of versatile synthetic strategies for magnetic materials with a controlled size, composition and structure has opened enormous possibilities for the preparation of heterogeneous or heterogenized homogeneous catalysts with magnetic properties [33-39]. Despite these impressive advances, the applications of magnetic catalysts are few and their magnetic properties were only used to facilitate separation [40-45]. The question arises and remains to be answered: Is it possible to get additional benefits from the magnetism of these elaborately designed magnetic catalysts? In heterogeneous catalysis, it is well documented that it is only in a correct reactor type that the merits of a catalyst can be used fully. So, is there a reactor type that can take full advantages of the magnetism of the magnetic catalysts? A promising reactor type for magnetic catalysts is the MSB reactor, which gives good mass and heat transport, and fine and friable catalyst particles can be used free from high pressure drops. The MSB reactor will play an important role in the industrial applications of nanometer catalytic materials.

\section{Acknowledgments}

The authors would like to express their sincere gratitude to Prof. Enze Min for his direction and help.

\section{References}

[1] Dudukovic M P. Science, 2009, 325: 698

[2] Filippov M V. Prik Magnit Lat SSR, 1960, 12: 215

[3] Rosensweig R E. Science, 1979, 204: 57

[4] Liu Y A, Hamby R K, Colberg R D. Powder Technol, 1991, 64: 3

[5] Saxena S C, Shrivastava S. Powder Technol, 1991, 64: 57

[6] Sikavitsas V I, Yang R T, Burns M A, Langenmayr E J. Ind Eng Chem Res, 1995, 34: 2873

[7] Wu W Y, Navada A, Saxena S C. Powder Technol, 1997, 90: 39

[8] Ganzha V L, Saxena S C. Powder Technol, 2000, 107: 31

[9] Hristov J Y. Powder Technol, 1998, 97: 35

[10] Chen C M, Leu L P. Powder Technol, 2001, 117: 198

[11] Miura H, Takahashi T, Ichikawa J, Kawase Y. Powder Technol, 2001, 117: 239
[12] Hu T T, Wu J Y. Chem Eng Res Des, 1987, 65: 238

[13] Kwauk M S, Ma X H, Ouyang F, Wu Y X, Weng D C, Cheng L N. Chem Eng Sci, 1992, 47: 3467

[14] Thompson V S, Worden R M. Chem Eng Sci, 1997, 52: 279

[15] Zong B N, Min E Z, Zhu Y S. CN 91111807.1.1993

[16] Mu X H, Zong B N, Min E Z, Wang X, Wang Y, Zhang XX, Shu X T. US 6368996. 2002

[17] Mu X H, Min E Z.J Chem Ind Eng (China), 1996, 47: 746

[18] Mu X H, Zong B N, Min E Z. Chem React Eng Technol, 1997, 13(2): 198

[19] Mu X H, Zong B N, Min E Z. Acta Petrol Sin (Petrol Process Sec), 1998, 14: 41

[20] Min E Z, Meng X K, Wen L Y. Petrol Process Petrochem, 2001, 32(9): 1

[21] Meng X K, Zhang X X, Zong B N, Min E Z. Petrol Process Petrochem, 2002, 33(1): 1

[22] Meng X K, Mu X H, Jiang Y S, Zong BN, Min E Z, Li B X, Zhu H J, Chen X B, Fu S B, Zhu Z H.J Chem Ind Eng (China), 2004, 55: 134

[23] Zhang J L, Zhang M, Li W, Li X F, Meng X K, Zong B N. Particuology, 2011, 9: 44

[24] Li W, Zong B N, Li X F, Meng, X K, Zhang J L. China Particuology, 2007, 5(1-2): 116

[25] Meng X K, Zong B N, Mu X H, Min E Z, Zhu Z H, Fu S B, Zhu H J, Li B X. Chem React Eng Technol, 2002, 18: 26

[26] Meng X K, Mu X H, Zong B N, Min E Z, Zhu Z H, Fu S B, Luo Y B. Catal Today, 2003, 79-80: 21

[27] Pan Z Y, Dong M H, Meng X K, Zhang X X, Mu X H, Zong B N. Chem Eng Sci, 2007, 62: 2712

[28] Yu G B, Sun B, Pei Y, Xie S H, Yan S R, Qiao M H, Fan K N, Zhang X X, Zong B N. J Am Chem Soc, 2010, 132: 935

[29] Peng Y, Dong M H, Men X K, Zong B N, Zhang J L. AIChE J, 2009, 55: 717

[30] Dong M H, Pan Z Y, Peng Y, Meng X K, Mu X H, Zong B N, Zhang J L. AIChE Journal, 2008, 54(5): 1358

[31] Zong B N. Catal Surv Asia, 2007, (1-2): 87

[32] Zong B N, Mu X H, Meng X K, Zhang X X, Min E Z. Acta Petrol Sin (Petrol Process Sec), 2006, 22(2): 1

[33] Sun S H, Murray C B, Weller D, Folks L, Moser A. Science, 2000, 287: 1989

[34] Redl F X, Cho K S, Murray C B, O’Brien S. Nature, 2003, 423: 968

[35] Mao C B, Solis D J, Reiss B D, Kottmann S T, Sweeney R Y, Hayhurst A, Georgiou G, Iverson B, Belcher A M. Science, 2004, 303: 213

[36] Yavuz C T, Mayo J T, Yu W W, Prakash A, Falkner J C, Yean S, Cong L L, Shipley H J, Kan A, Tomson M, Natelson D, Colvin V L. Science,

\section{Graphical Abstract}

Chin. J. Catal., 2013, 34: 61-68 doi: 10.1016/S1872-2067(11)60476-2

\section{Magnetically stabilized bed reactor}

ZONG Baoning*, MENG Xiangkun, MU Xuhong, ZHANG Xiaoxin Research Institute of Petroleum Processing, SINOPEC

The magnetically stabilized bed reactor combines the advantages of the fixed bed, moving bed and fluidized bed reactors to intensify the hydrogenation process.

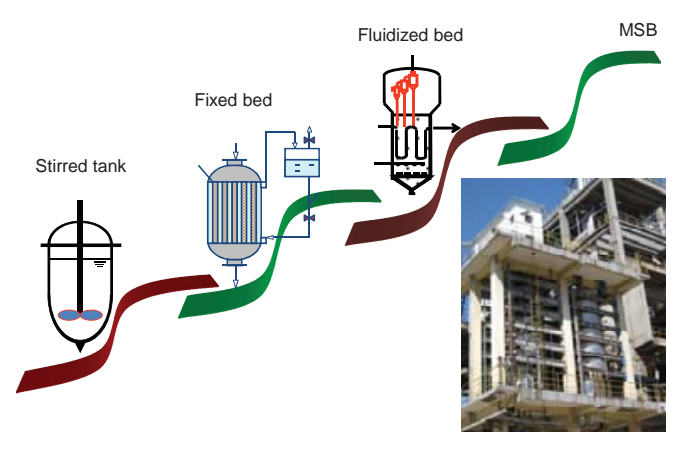


2006, 314: 964

[37] Lu A H, Salabas E L, Schüth F. Angew Chem, Int Ed, 2007, 46: 1222

[38] Latham A H, Williams M E. Acc Chem Res, 2008, 41: 411

[39] Shylesh S, Schünemann V, Thiel W R. Angew Chem, Int Ed, 2010, 49: 3428

[40] Tsang S C, Caps V, Paraskevas I, Chadwick D, Thompsett D. Angew Chem, Int Ed, 2004, 43: 5645
[41] Abu-Reziq R, Alper H, Wang D S, Post M L. J Am Soc Chem, 2006, 128: 5279

[42] Panella B, Vargas A, Baiker A.J Catal, 2009, 261: 88

[43] Jin M J, Lee D H. Angew Chem, Int Ed, 2010, 49: 1119

[44] Polshettiwar V, Luque R, Fihri A, Zhu H B, Bouhrara M, Basset J M. Chem Rev, 2011, 111: 3036

[45] Lai D M, Deng L, Guo Q X, Fu Y. Energy Enivron Sci, 2012, 4: 3552

\section{磁稳定床反应器}

宗保宁*, 孟祥糜, 慕旭宏, 张晓昕

中国石油化工股份有限公司石油化工科学研究院，催化材料和反应工程国家重点实验室，北京 100083

摘要: 介绍了磁稳定床反应器在国际上的首次工业应用,它集成了浆态床、固定床、移动床和流化床等反应器的优点. 通过调整线 圈间距、在反应器内设置磁隔栅构件, 实现了均匀磁场的放大; 绘制出磁稳定床反应器链式操作相图. 将非晶态 $\mathrm{Ni}$ 优异的加氢性 能和磁性与磁稳定床反应器反应过程强化性能相结合, 实现了在已内酰胺加氢精制过程的工业应用, 并建成 5 套 20 40万吨/年工 业装置. 磁性催化剂与磁稳定床反应器相结合, 强化了甲烷化、乙炔选择性加氢和烯烃叠合等反应过程, 形成了新技术生长点. 关键词：磁稳定床；磁性催化剂；选择性加氢；一氧化碳甲烷化；烯烃叠合; 工业化

收稿日期: 2012-08-20. 接受日期: 2012-10-29. 出版日期: 2013-01-20.

*通讯联系人. 电话/传真: (010)82368011; 电子信箱: zongbn.ripp@ sinopec.com

基金来源: 国家重点基础研究发展计划 (973 计划, 2012CB224806).

本文的英文电子版由Elsevier出版社在ScienceDirect上出版(http://www.sciencedirect.com/science/journal/18722067). 